\title{
IN-SERVICE REMEDIATION OF A RAILWAY EMBANKMENT TO PREVENT SETTLEMENT
}

\author{
JAN GREPL
}

\author{
Dipont, s.r. o., Libouchec 505, 40335 Libouchec \\ correspondence: grepl@dipont.cz
}

\begin{abstract}
After optimization of the railway geometry for higher speed, a continuous settlement of the track occurred. Improvement of the embankment body was needed; however, a complete traffic interruption was not allowed. The reconstruction work has been done using the methods of special ground engineering such as vibro-stone columns and driven ductile piles.
\end{abstract}

KEYWORDS: Railway embankment settlement, vibro-stone columns, ductile piles.

\section{INTRODUCTION}

With optimization of the double track to a higher speed, an increase of the curve radius occurred. The embankment had to be extended. Later, deformations of the extended earth body appeared. To achieve a safe service on the track, both tracks needed to be rectified very often. Based on several geotechnical surveys and monitoring, it was ascertained that the deformations originated inside the embankment. The influence of subsoil deformation as well as sliding influence were excluded. The low value of the global deformation modulus of the embankment had probably been the cause of the deformation. The article describes the design and the in-service implementation of the $16 \mathrm{~m}$ high railway embankment repair. Work was done according to the requirements of the track operator. At least one track of the double track needed to be in service given the demand for a maximum 90 days service disruption.

\section{DESCRIPTION OF LOCATION AND THE ORIGINAL CONDITION}

The double corridor track is located at the left sided curve with a radius of $725 \mathrm{~m}$ and elevation of $135 \mathrm{~mm}$. The parameters had been designed for a track velocity of $120 \mathrm{~km} / \mathrm{h}$. The part of the track which has been dealt with is $400 \mathrm{~m}$ long and is at the embankment of a variable height of $5-16 \mathrm{~m}$ with bridges on both sides. The curve radius needed to be extended. Due to the constricted conditions, the embankment extension close to the abutment has been built from a reinforced earth structure. The slope of the embankment extension close to the abutment was very steep. The crown of the old embankment, which was unused after optimization work, was adjusted into a slope of $2 \%$ with a direction out of the curve. The surface of the top has been compacted and stabilised with cement (see Figures 1 and 2 . The track has been drained by an open ditch between the rails and the loosened top of the original embankment.

\section{RECORDED DEFECTS ON THE TRACK AND ITS CAUSES}

\subsection{DeFECTS ON THE TRACK}

The deformation of the rails had been the biggest problem on the track. The first indications about problems with embankment settlement occurred just a few months after the track was back in service. Not long after that, problems with the earth structure connected with high water content occurred (cracks and gaps in the facing wall, a watery base of the slope at the facing wall, local outflow from the earth structure). The tendency of embankment settlement was not decreasing, and there was a need to rectify the track frequently.

With respect to these problems geotechnical surveys using geophysical measurement were performed as well as the cone penetration testing and bore holes.

\subsection{Probable causes of the embankment DEFECTS}

Due to these constant problems with the embankment settlement the causes of these vertical deformation could be defined additionally thanks to a complementary survey.

Insufficient value of the global deformation modulus of the embankment material has been discovered as the origin of the deformation. This has been caused by a combination of the following:

- the incorrect technological procedure of the embankment building process (insufficient compaction, free swelling etc.),

- the inappropriately chosen material for the embankment extension (slate of different levels of weathering, time degradation).

The earth structure material is very sensitive to the water content. Other influences contributed to the continual deformation. Those influences caused infiltration of the rainwater into the earth structure. Mainly it was about the open top of the original embankment and a non-functional drainage of the track 


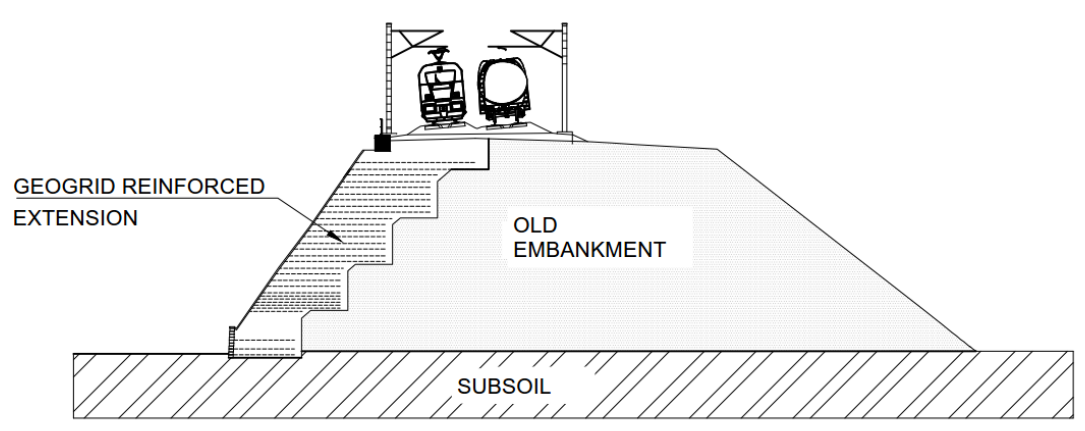

FIGURE 1. Existing condition - extension with geogrids.

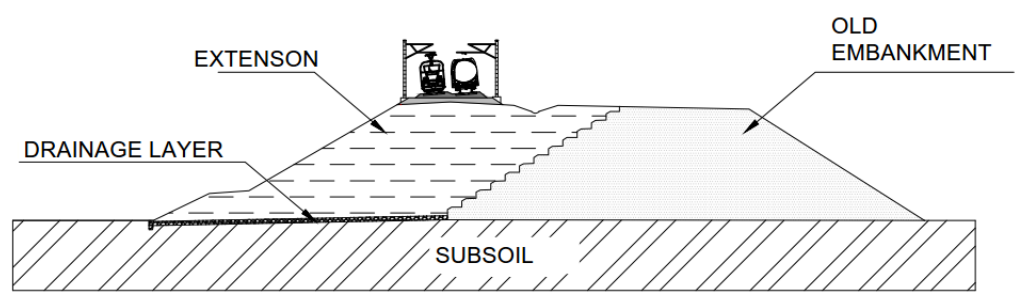

FiguRE 2. Existing condition - unreinforced embankment.

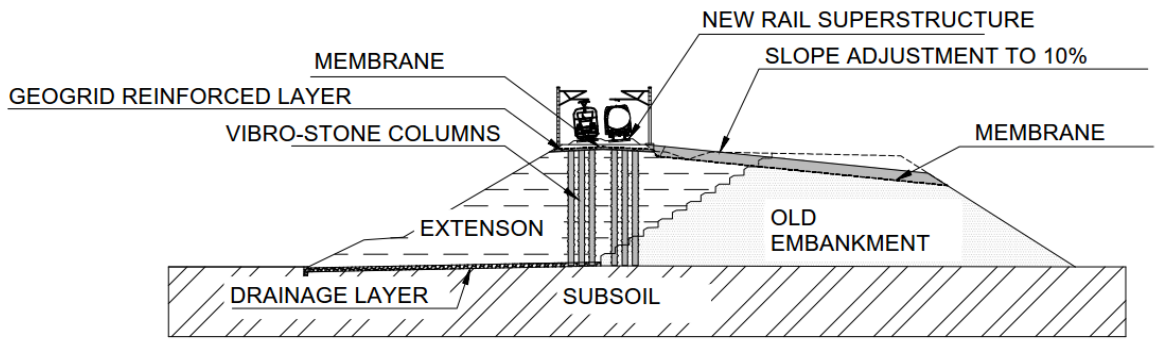

FiguRE 3. Concept for improvement of the non-reinforced embankment.

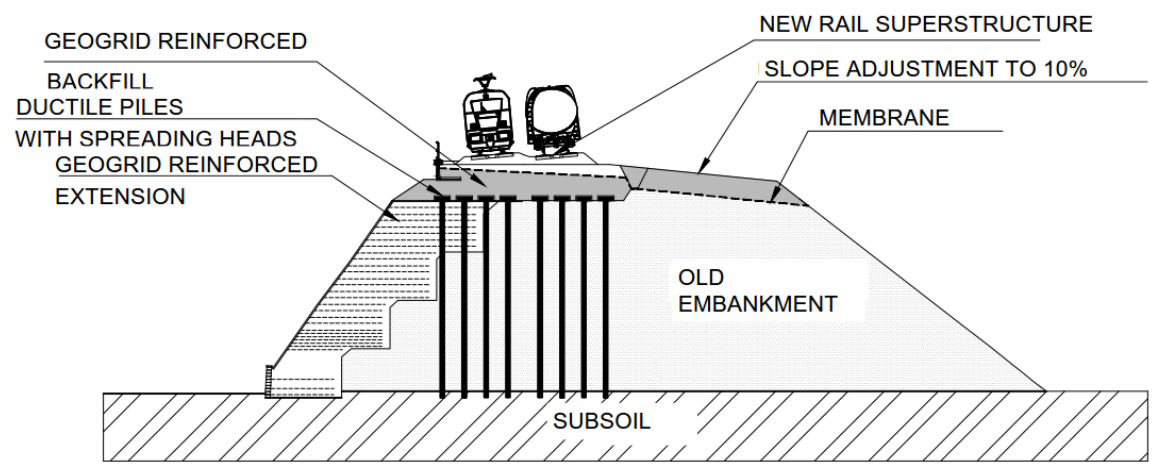

Figure 4. Concept for improvement of reinforced embankment. 
with an open ditch. The non-functional drainage close to the bridge abutment contributed to the deformation of the transition zone. This abutment drainage was interrupted. The gradual deformation of the earth structure and constant rectification of the track caused a penetration of the ballast to the subgrade and non-function of the drainage. This fact led to the saturation of the embankment with rainwater which caused the degradation of the coarse material into a fine clay.

\section{Main Steps to improve the EMBANKMENT}

When the causation of the embankment deformation was clarified, the main steps of the improvement were defined. These were intended to eliminate the deformation and stabilize the geometrical track position. The following steps were taken:

- Embankment drainage to lower the water content.

- Homogenization and compaction of the earth body, which had degraded.

- Prevention of significant rainwater inflow to the earth body.

- Recovery of the subgrade and its functional drainage.

\section{BOUNDARY CONDITIONS FOR THE IMPROVEMENT DESIGN}

The main steps in the improvement had been defined. Boundary conditions had been taken into account for the choice of technology.

At least one track in service (electric traction included) had been the essential condition restricting the improvement design. Maximal disruption time had been limited to 90 days in accordance with other works on the track. These conditions excluded complete excavation of the inappropriate material of the earth structure and its rebuilding from a suitable material. The electric traction in service also influences very significantly the technological procedure.

The access on the embankment body was allowed only from one side, at the place where the track is coming to its cut. The loosened top of the original embankment provided sufficient manipulation space. The condition of the track in service caused the one track in service to limit access to the other track.

\section{Method And TeChNology of THE IMPROVEMENT}

\subsection{The IMPROVEMENT CONCEPT}

Considering the basic steps of the improvement and the given conditions, the concept for the improvement was chosen. The substructure would be improved with installation of vibro-stone columns [1]. The released crown of the old embankment would be arranged for a greater slope and sealed with watertight membrane. Membrane would be also laid under the sub-ballast.

Vibro-stone columns installed to the earth structure would drain the body, solving the problem associated with the high water content. When installing the vibro-stone columns, the gravel is pushed to the sides and it would also compact the existing material around them [2].

The watertight membrane installed around all the area of the embankment top would provide a permanent barrier to the rainwater (see Figure 3 .

At the part where the embankment extension was reinforced with geogrids the vibro-stone columns would not be possible to use. Reinforced geogrids would obstruct the technology of the columns installation. If the columns crossed the geogrids, its anchor length would break and the stability of the steep slope could be also broken. These are the reasons why the improvement of the bridge transition zone and its close parts were designed with driven ductile piles with precast reinforced concrete heads. Ductile piles have been installed in the regular triangle grid, around $2 \mathrm{~m}$ under the subgrade. On the piles concrete spreading heads have been placed and the construction has been covered using gravel with geogrids (see Figure 4).

\subsection{Procedural PRogress}

Work procedure had to be adjusted to the requirements of the lockout of the track and also to limited access to the embankment top. It was designed firstly under the track no. 1, which was located closer to the earth structure slope. The improvement under the track no. 2 followed just after the work of the track no. 1 improvement had finished. To access the track no. 1 it was necessary to build an access platform as it was not allowed to cross the track no. 2 in service.

Before the track no. 1 lockout, the super-elevation in the track no. 2 needed to be removed, the traction included. When the track no. 1 was not in service, the superstructure was removed, and the sheeting of the ballast shoulder was done. In the transition zone a soldier pile wall with HEB 140 profiles was chosen.

After the removal of superstructure and ballast, a space with the width of $5.5 \mathrm{~m}$ was formed for the installation of the stone columns. The workspace was bounded by the track in service from one side and the embankment slope from the other side. It was very difficult to plan the work procedure. The area close to the machine for the stone columns production was very narrow and it was not able to pass by with other forms of mechanization. Due to the length of the columns $(15 \mathrm{~m})$, it was necessary to do a pilot borehole with a CFA drilling machine (see Figure 5).

After all stone columns were fixed, the excavation at the transition zone could be done. The installation of the ductile piles followed. At the same time repair to the insulation of the bridge abutment was made. Finally, the watertight geo-membrane, the sub-ballast and ballast were laid. The superstructure was laid to 
the original geometry with zero super-elevation (see Figure 6.
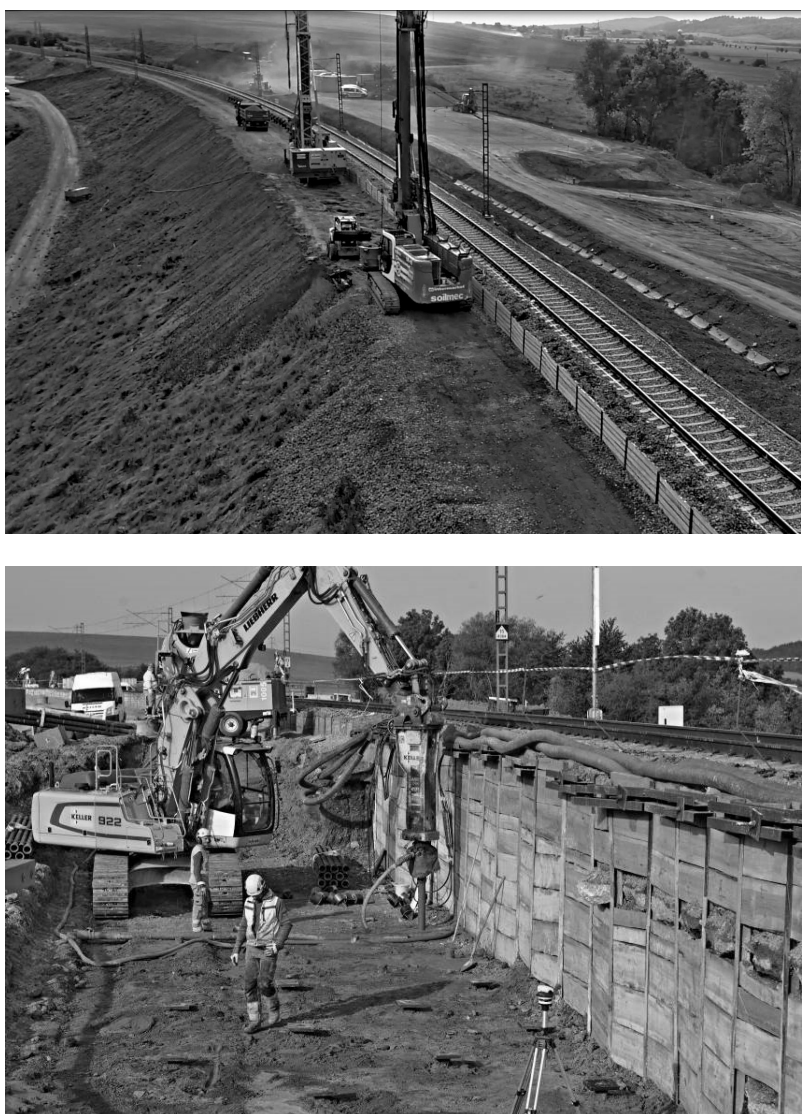

FigURE 5. Stone columns procedure under the track no. 1. (top) and procedure of the Ductile piles under the track no. 1 (bottom).

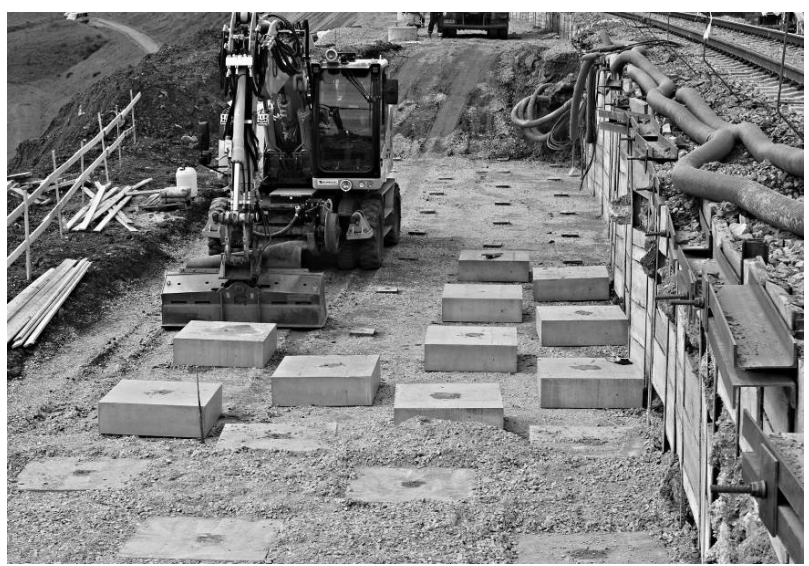

Figure 6. Procedure of the spreading heads under the track No. 1.

As the track No. 1 was brought into service, the superstructure of the track No. 2 was removed. The procedure was repeated. The vibro-stone columns were fixed. The bridge transition zone was excavated for the ductile pile installation. The bridge abutment insulation was repaired as well. Work on the crown of the old embankment was finishing at the same time. After the stone columns and the ductile piles installation, the backfill of the transition zone was done. This was laid and connected to the membrane under track No. 1 and the membrane on the crown of the old embankment. Finally, the track superstructure was laid and both tracks were adjusted to its final geometry.

The service was restored in both tracks and the final work was performed away from the track in service (see Figure 7).
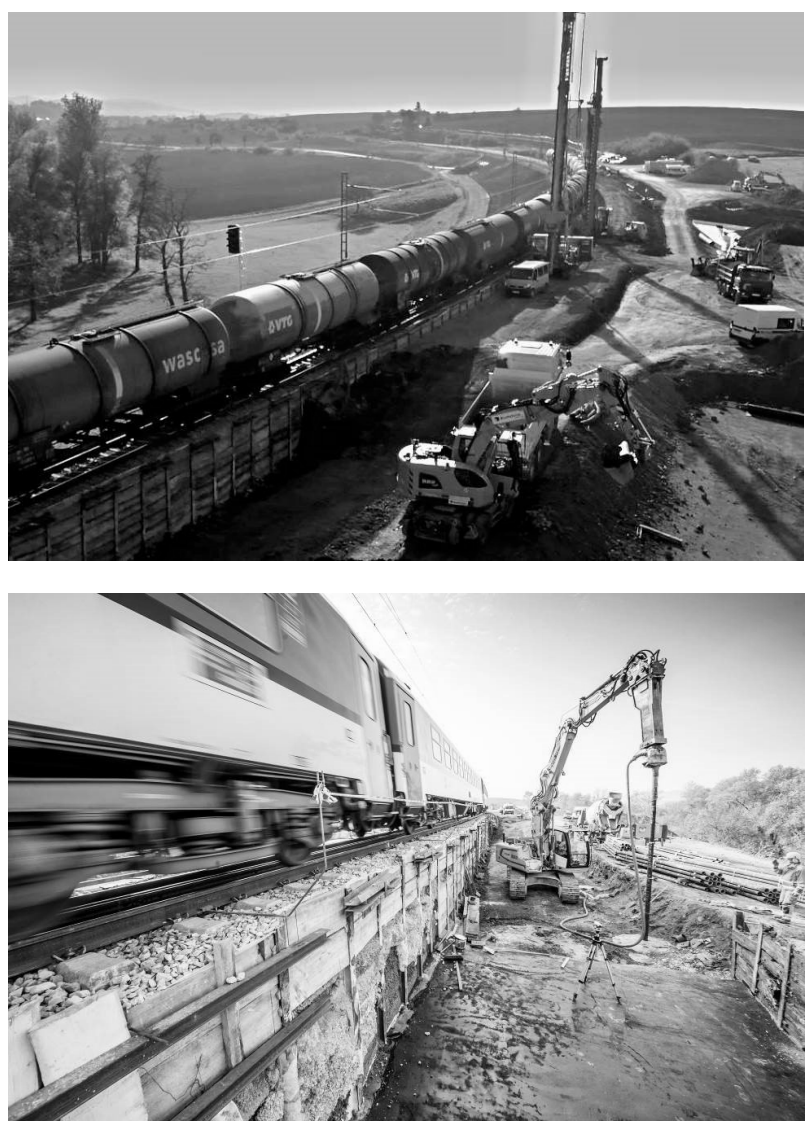

FiguRE 7. Vibro-stone columns and excavation for ductile piles under the track no. 2 (top) and ductile piles hammering under the track no. 2 (bottom).

\section{EsSENTIAL CONSTRUCTION PARTS}

\subsection{VIBRO-STONE COLUMNS}

Vibro-stone columns have been designed in $700 \mathrm{~mm}$ diameter, placed in triangular raster with $1500 \mathrm{~mm}$ distance. The drainage layer on the base of the embankment had to be reached by the columns in order to achieve the best drainage effect. The maximum column length was $15 \mathrm{~m}$.

In order to achieve the maximum length of the columns and to speed up the works, it was decided to install the columns into the pilot bore diameter of $500 \mathrm{~mm}$. Under each track, 402 pieces of vibro-stone columns were fixed, a total of 804 pieces. In the first stage under track No. 1 there were 5,400 meters of columns installed in 19 days. In the second stage under track No. 2, 5,900 meters of columns were completed in the same period (see Figure 8). 


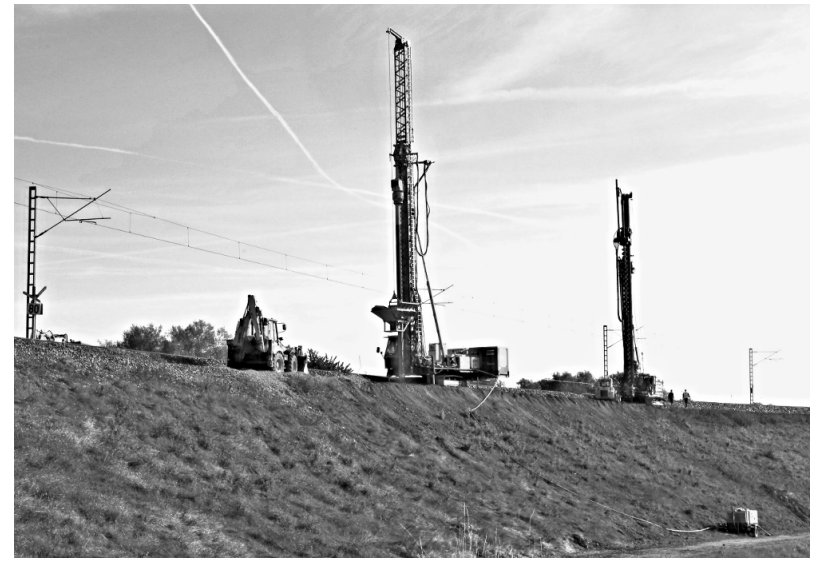

FiguRE 8. Vibro-stone columns installation under the track no. 1.

\subsection{DRIVEN DUCTILE PILES}

The use of ductile piles was chosen with regard to the necessity for passing through the geogrid reinforced body. The industrially pre-fabricated piles from highstrength ductile cast iron are joined to a pile shaft of variable length without using special tools and then driven into the soil. Ductile piles are driven while simultaneously grouting the concrete mortar or cement suspension into the annulus between the tube and the grout shoe (this gives an increase in load capacity and corrosion protection). The driving of additional tubes to the required depth is achieved.

Resistance is recorded during the installation to indicate the load capacity.

This also paid off during construction, when the sufficient load-bearing capacity was not achieved at the planned depth of $12 \mathrm{~m}$. The piles were operatively extended.

The pilot head was equipped with a prefabricated reinforced concrete distribution head. The head provided a connection with the geogrid reinforced backfill. In the first phase under track No. 1, more than 700 meters of the piles, including grouting, were done in less than two days. A similar installation speed was achieved in the second phase.

\section{Conclusion}

The reparation of the railway embankment to prevent its settlement was carried out in a very short time and in a place with a very difficult access. One track was always in service. The given task would not have been completed in time without the use of modern methods of deep foundation. In this case, the cooperation of the designer and the deep foundation works contractor proved successful.

\section{REFERENCES}

[1] R. Fiala, J. Boštík, A. Kotačková, et al. Technologie štěrkových pilíruo pro praxi: (navrhování, prováděni a kontrola). Akademické nakladatelství CERM, Brno, 2014.

[2] P. Svoboda. Hloubkové zlepšování zemin v české praxi. Akademické nakladatelství CERM, Brno, 2009. 